\title{
Optimization of the Fuel Distribution Business by Application of the Bellman-Kallaba Algorithm: A Case study of the Network of the TOTAL Company in Kinshasa-DRC
}

\author{
Yondo Ngandu Vially \\ Faculty of Oil, Gas and New Energies \\ Department of Petrochemistry and Refining \\ University of Kinshasa, DR Congo
}

\begin{abstract}
This research work has made it possible to develop tools adapted to the needs of fuel distribution network operators. It is the mapping of the network with the GIS arc software, the modeling of the network by exploiting the notions of strongly connected graph and the application of the BELLMAN KALLABA algorithm on the model of the network.

These tools allow managers to determine, from the fuel distribution network modeling, for each tour, the optimal routes, the stations to be visited, the routes to be made, the trucks to be used, the quantities to be delivered for each product and their assignment to trucks taking into account quality and safety requirements. The application of the approach as part of a case study carried out on TOTAL's distribution network in Kinshasa yielded some interesting results.
\end{abstract}

The results obtained are a decision aid for the managers of the fuel distribution networks, whose mission is to minimize the total cost of distribution, maximize the quantity to be delivered and optimize any other economic objective over a given planning horizon.

Keywords: Optimization, Network, Bellman-Kallaba, Fuel Distribution.

\section{INTRODUCTION}

An examination of the location of oil reserves in the world as well as that of the various refineries and consumption zones shows immediately that a very large portion of the derived products will have to be transported in massive quantities over very large distances. The production zones are very often indeed areas of consumption. The supply problem for service stations is for the utility to determine how to best distribute multiple fuels (mainly gasoline, kerosene and diesel fuel) to service stations from one or several deposits according to one planning horizon chosen and according to optimal itineraries.in other words, how can we enumerate, without repetition and redundancy, all the optimal elemental paths of the fuel distribution network, which is a transport problem in the mathematical sense. [1]

It is thus necessary to determine, starting from the modeling of the distribution network of the fuels, for each way, the optimal routes, the stations to be visited, the rounds to be carried out, the trucks to be used, the quantities to deliver each product and their assignment to the trucks by taking account of the requirements of quality and safety, and this, by making sure that no station customer is in out-of-stock condition. This study aims at solving the graph rising from the modeling of the TOTAL distribution network.

\subsection{Study context}

Road transport is the main route of fuel distribution in a network of service stations with tanker truck tours. However, in recent years, oil companies have contracted private carriers to distribute their petroleum products to their service stations in a specific territory. To the best of our knowledge, carriers have a manual supply planning schedule. Generally this activity is mainly based on the experience of the dispatcher who must have a good knowledge of the geography of the territory to be served. 
Modes of transportation vary according to several criteria. In the Democratic Republic of Congo (DRC), there are four transport routes for fuels:

$\Rightarrow$ The seaway;

$\Rightarrow$ The railway track;

$\Rightarrow$ The waterway;

$\Rightarrow$ The road way.

It is thus by this route of transportation that the 24 service stations of the TOTAL company in Kinshasa are supplied with fuel for retail sale from two depots SEP-CONGO.

\subsection{Network presentation.}

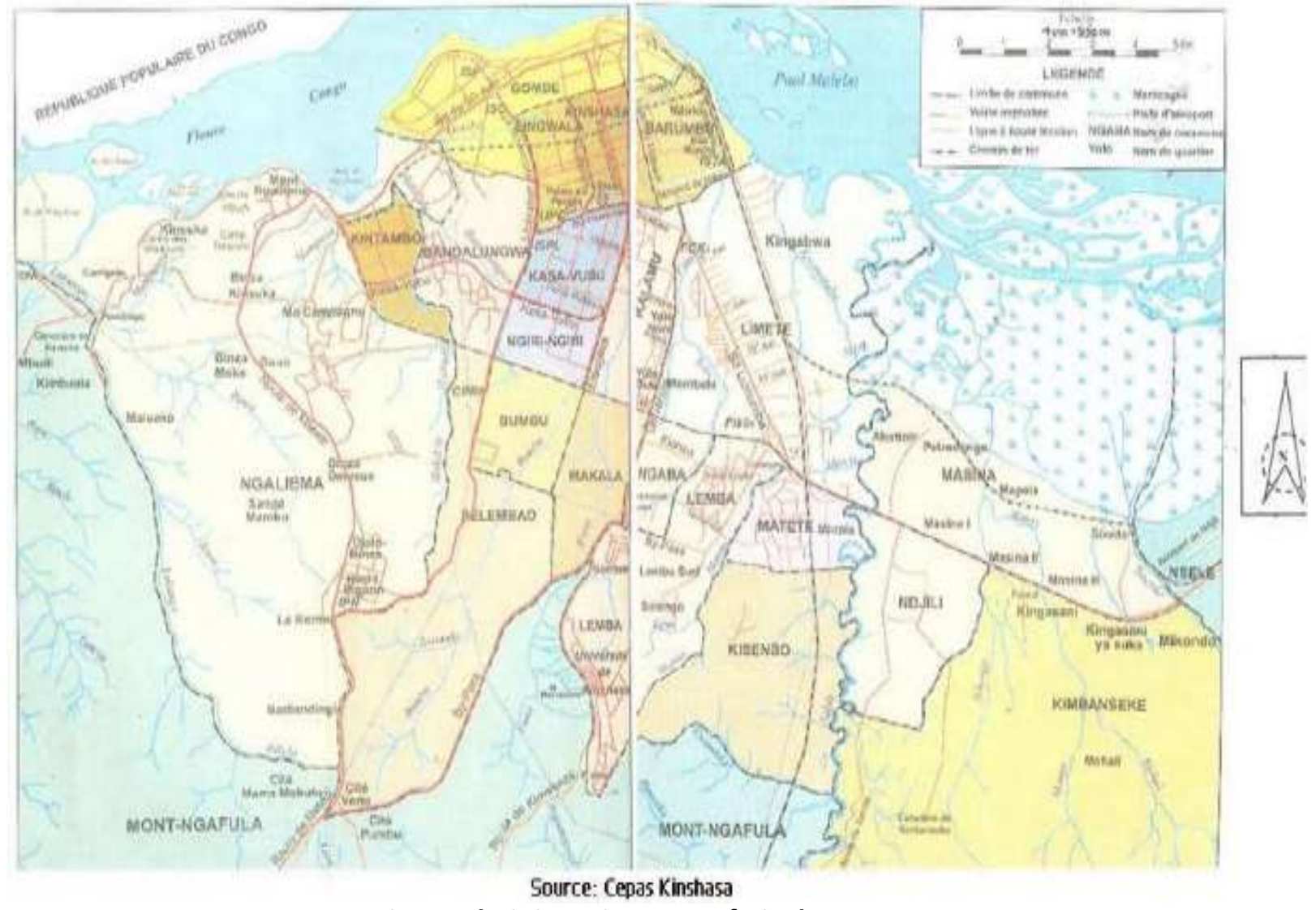

Fig 1: Administrative map of Kinshasa

by TOTAL network we mean a set of TOTAL service stations interconnected by the reliable road network for a defined exploitation and whose activity planning is organized around two nodal points which are the depots of Sep Congo (city of Kinshasa).

The TOTAL-Kinshasa network is composed of 25 petrol stations, 2 petroleum depots and the main roadways that can be used linking any couple of petrol stations and any station-depot combination.

given the geographical distribution of the service stations in the city of Kinshasa, the existence of the road lanes between stations, the distance between the stations and the serviceability of the depots, the TOTAL-Kinshasa network can be expressed by the combination activities of two sub-networks (TOTAL East and TOTAL West) which connect the TOTAL service stations of KinEast and Kin-West respectively. In this way, the TOTAL East sub-network will have Masina's base as a nodal point, while the Kinshasa (Gombe) base will act as the root node of the West TOTAL network.

Two SEP-CONGO depots (Masina and Gombe) supply TOTAL-Kinshasa's distribution network in satisfactory quantities of gasoline, gas oil and kerosene, and each network service station has the storage capacities of these products. The various points (stations) of the network are connected by a road network whose lanes allow the circulation of tanker trucks in a secure way more or less safe from any act of sabotage. the roads used are: Avenue Bokasa, Kasavubu Avenue, Kasaï Avenue, Kabambare Avenue, Boulevard du 30Juin, Boulevard des Poids Heuvel, Avenue Flambeau, Avenue Aerodrome, Avenue du 24 November, 
Avenue of Liberation, Avenue Laurent Désiré Kabila , Road Matadi , University Avenue, AvenueKianza, Kapela Avenue, Lumumba Boulevard, Petro Congo Avenue, Sous-region Avenue, Kiyimbi Avenue, Super Avenue, Pompage Road, fleuve Road.

Table I: The various gas stations and depots making up the TOTAL-Kinshasa network (June 2015)

\begin{tabular}{|c|c|c|c|c|c|c|c|}
\hline \multirow[t]{2}{*}{ Station Name } & \multirow[t]{2}{*}{ Longitude } & \multirow[t]{2}{*}{ Latitude } & \multirow[t]{2}{*}{ Altitude } & \multirow[t]{2}{*}{ Location } & \multicolumn{3}{|c|}{ Ability } \\
\hline & & & & & Gas oil & Gasoline & Kerosene \\
\hline F/S Kabambare & 15,31749 & $-4,32032$ & 284 & Bokasa-Kabambare & 20 & 20 & - \\
\hline F/SNgongolutete & 15,30338 & $-4,30328$ & 292 & Gombe & 11 & 20 & - \\
\hline Base SEP Gombe & 15,32114 & $-4,30179$ & 287 & Poids lourds & & & \\
\hline F/S kingabua & 15,34636 & $-4,35101$ & 292 & 8ième Rue Poids lourds & 60 & 40 & - \\
\hline F/S Flambeau & 15,32867 & $-4,31022$ & 285 & En face de la Bralima & 15 & 30 & - \\
\hline F/S Kintambo & 15,25844 & $-4,33357$ & 298 & Rond-point Magasin & 17.5 & 11 & - \\
\hline F/S Pompage & 15,19339 & $-4,36156$ & 301 & Terminus mbudi & 15 & 15 & - \\
\hline F/S Delvaux & 15,25911 & $-4,38001$ & 446 & Laurent désiré Kabila & 50 & 40 & - \\
\hline F/S Sanatorium & 15,28263 & $-4,38112$ & 383 & Avenue de la libération & 30 & 40 & 15 \\
\hline F/S Molaert & 15,29125 & $-4,34844$ & 299 & Rond-point Molaert & 40 & 50 & - \\
\hline F/S Joli Parc & 15,26399 & $-4,3465$ & 314 & Entrée ma campagne & 30 & 60 & - \\
\hline F/S Ecole & 15,28886 & $-4,31155$ & 277 & Boulevard/24novembre & 40 & 30 & - \\
\hline F/S Du Peuple & 15,29646 & $-4,32809$ & 288 & En face de la RTNC & 40 & 40 & - \\
\hline F/S Université & 15,32178 & $-4,36403$ & 298 & Kapela-Université & 12 & 22 & - \\
\hline F/S Fikin & 15,34172 & $-4,36648$ & 299 & 15 ième Rue Limete & 60 & 60 & - \\
\hline F/S Megastore & 15,34789 & $-4,36951$ & 301 & Concession Plazza & 16.5 & 16.5 & - \\
\hline F/S Eucalyptus & 15,3749 & $-4,3907$ & 310 & Boulevard-Kimbuta & 40 & 40 & 10 \\
\hline F/S Echangeur & 15,34428 & $-4,37514$ & 304 & Echangeur de Limete & 20 & 41 & - \\
\hline Base SEP Masina & 15,37538 & $-4,37538$ & 296 & Route Petro-congo & & & \\
\hline F/S Kingasani & 15,41239 & $-4,40465$ & 314 & Commune/Kimbanseke & 30 & 40 & 10 \\
\hline F/S Kinkole & 15,51066 & 4,34378 & 324 & Boulevard vers Kinkole & 22 & 38 & - \\
\hline F/S Matete & 15,34504 & $-4,39002$ & 308 & Matete marché Tomba & 11 & 41 & - \\
\hline F/S Marché & 15,34556 & $-4,3916$ & 304 & Marché Matete & 10 & 20 & 10 \\
\hline F/S Assossa & 15,30226 & 4,34653 & 302 & Assossa-Force & 20 & 40 & - \\
\hline F/S Benseke & 15,25802 & $-4,4342$ & 428 & Badiadingi & 35 & 55 & - \\
\hline F/S Benseke II & 15,28648 & $-4,41582$ & 428 & Route Matadi & & & \\
\hline & & & & & & & \\
\hline
\end{tabular}

\subsection{Formulation of the problem}

The optimization of distribution activities in a network consists in supplying the service stations of the network with fuels from a central repository according to a given planning horizon while exploiting the optimal routes of the network. Each customer consumes the product at a more or less constant rate by having the ability to locally store a product in a single receive. The distribution is made by means of a compartmentalized tank vehicle fleet. Each service station requires fuel based on its storage capacity and customer base.

Therefore, for each tour, the service stations to be supplied, the quantity to be delivered and the route to be followed for each tanker truck must be determined to minimize distribution costs

Generally, in the carriers, the planning of the supply of a distribution network is done manually by routine without any objective scientific criterion. In addition, this activity is mainly based on the experience of the dispatcher who must have a good knowledge of the geography of the territory to be served. [2]

The constraints are numerous during the distribution:

For reasons of safety and balance of the truck, the contents of the first or second compartment (on the tractor side) must be delivered to the last station visited during a tour; 
$\Rightarrow$ During a tour serving several stations, the nearest stations must be visited first to reduce the weight of the truck during transport;

$\Rightarrow$ At variable temperatures some petroleum products lose their light fraction by evaporation during transport.

\section{LITERATURE REVIEW}

A simulation model SNEW was proposed to determine the cost of supplying selected customers and the vehicle routing method for all customers to be served to deliver the allocated quantities in a study of the interdependent distribution problem inventory and vehicle routing issues for an energy products company that distributes liquid propane to its customers. Simulation experiments showed good results with an improvement of 8,4\% in production, a 50\% reduction in stockouts and a total cost of 23\%. [3]

The problem of the routing of stocks can be approached as a particular case of problem of routing of the vehicles during a single day. A review of stochastic demands and non-linear inventory costs allowed the suggestion of a non-linear whole number programming formulation for the inventory and tour problem. Non-linear whole number programs have the property that for any assignment of clients to routes, the problem is broken down into an inventory allocation problem and a number of commercial traveler problems. Starting with an initial allocation of inventory, iteratively applying exchange heuristics to create a better set of itinerant visits and an optimization procedure to improve stock allocation. This algorithm procedure ends when it is no possible to improve the total inventory and tour costs. The results show that it is possible to save about 6 to $7 \%$ of operating costs by using the combined approach for inventory allocation and vehicle tours, as compared to separate conventional solutions. [1]

Another whole-number programming model, which attempts to find a less myopic solution by passing inventory information from one day to the next. A Lagrangian procedure has been proposed to generate the upper and lower limits of feasible solutions to the problem of inventory and routing; good results have shown the effectiveness of the proposed procedure. [4]

To solve the problems of inventory allocation and vehicle routing over a long period, an approach has been proposed to take into account what happens after the one-day planning period. it is a reduced procedure for which the long-term effect of the problem can be integrated in a short-term period, so that long-term delivery costs are minimized and no customer is short-term in stock at any time during the planning period.[5].

A study was conducted to minimize long-term average transport and inventory costs by determining long-term routing patterns. she analyzed the fixed partition strategies of the stock tour problem with constant deterministic demand rates and an unlimited number of vehicles. Tour patterns are determined using a modified circular score scheme. Once the clients are partitioned, the clients of a partition are distributed in regions to generate the demand for each region. A customer may appear in more than one region, but a certain percentage of the customer's request is allocated to each region. When a customer from a region receives a visit, all customers in the region are visited. A lower limit for the long-term average cost is also determined by which the performance of the determined route models can be evaluated. [6]

\section{MATERIALS AND METHODOLOGY}

\subsection{Materials}

We used the following materials:

$\Rightarrow$ The cartography of the city of Kinshasa

$\Rightarrow$ GPS

$\Rightarrow$ ARC GIS Software; OPT SOLVER Software; GOOGLE EARTH, GRIN 4.0

\subsection{Methods}

\subsubsection{Descent on ground}

The objective of the field being to take the geographical coordinates of the stations and to measure the distances separating all the couples from the points (vortex) of the network. The main activities of the mission are:

\section{Travel in network routes and distance measurement}

Using GPS, the distance measurement between different points of the network is carried out using the GPS by activating the route measurement function.

\section{Collection of geographical coordinates}

Arrival at the station, the sampling of geographical coordinates is done thanks to the GPS while making sure that the precision is of the order of \pm 3 meters. Longitude and latitude are taken in decimal degrees while altitude is taken in meters. 
International Journal of Advances in Scientific Research and Engineering (ijasre), Vol 5 (10), October-2019

\section{Collection of data related to storage capacities}

Storage capacities are total volumes of buried tanks for each product. It is a fact that the oil tankers consider confidential, but yet clearly mentioned in all the covers of underground tanks for security reasons.

\subsubsection{Network mapping}

Network mapping was made possible through the use of Arc GIS software. After filtering and processing data related to the geographic coordinates of gas stations (see Table 1), we can easily develop the TOTAL Kinshasa network map.

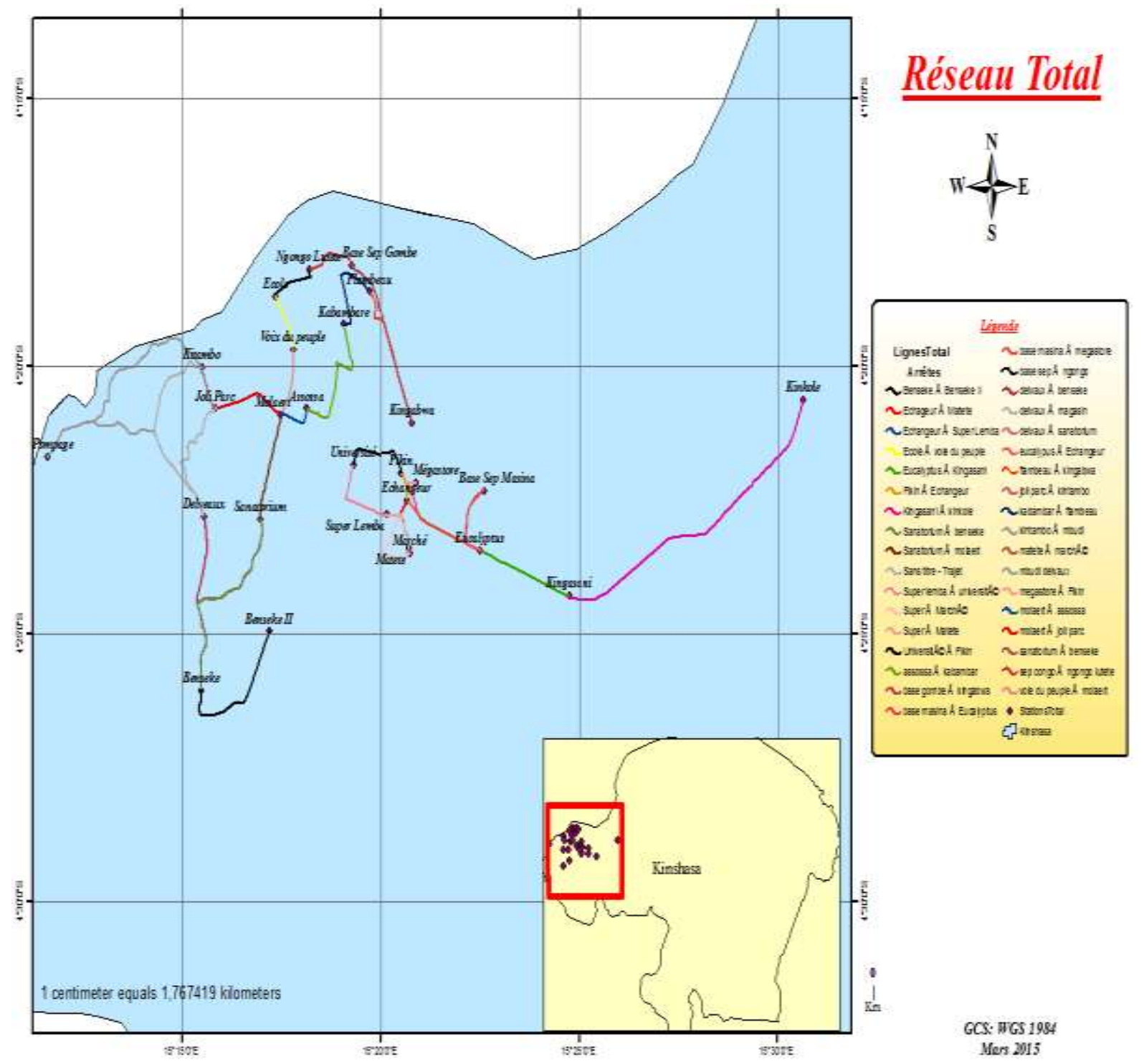

Fig .2: Mapping of the TOTAL-Kinshasa network (V. Yondo., 2015)

Looking at this map, the distinction between the East and West sub networks is clearly visible, as well as the number of stations that make up each of the sub networks. This map finally allows us to model the network in graphs according to the sub-networks. 


\subsubsection{Network modeling}

\section{Hypotheses}

$\Rightarrow$ The three products distributed in the network are: super, G.O and oil;

$\Rightarrow$ The return of the empty truck to the depot does not constitute a constraint;

$\Rightarrow$ All the performance criteria of the transport and distribution activity;

$\Rightarrow$ Delivery is done station by station from the depot by following the optimal path station-depot;

$\Rightarrow$ The tanker trucks carrying the products are multi-compartmented.

\section{Graph construction}

Let $\mathbb{G}=(\mathbb{X}, \mathbb{U})$ be a weighted graph of order $n$, such that:

$\mathbb{X}=\left\{x_{1}, x_{2}, x_{3}, \ldots, x_{n}\right\}:$ The service station set of the network such as $x_{i} \neq x_{j}$.

$\mathbb{U}=\left\{\left(x_{i}, x_{j}\right) \in \mathbb{X} \times \mathbb{X} / x_{i}\right.$ et $\left.x_{j} \in \mathbb{X}\right\}$ : Set of road sections that connect any station pair. Thus, the weights of the arcs are the distances in kilometers separating the service stations from each other. They are obtained either by measurement on land of the routes with the GPS, or by exploiting the aerial photo images of GOOGLE EARTH

All points of the network are interconnected either by sections of road or by a succession of road sections whose ends are points (service station) of the network. So in practice $U$ is the set of bow that exactly materializes the journey of tanker in the network of gas stations.

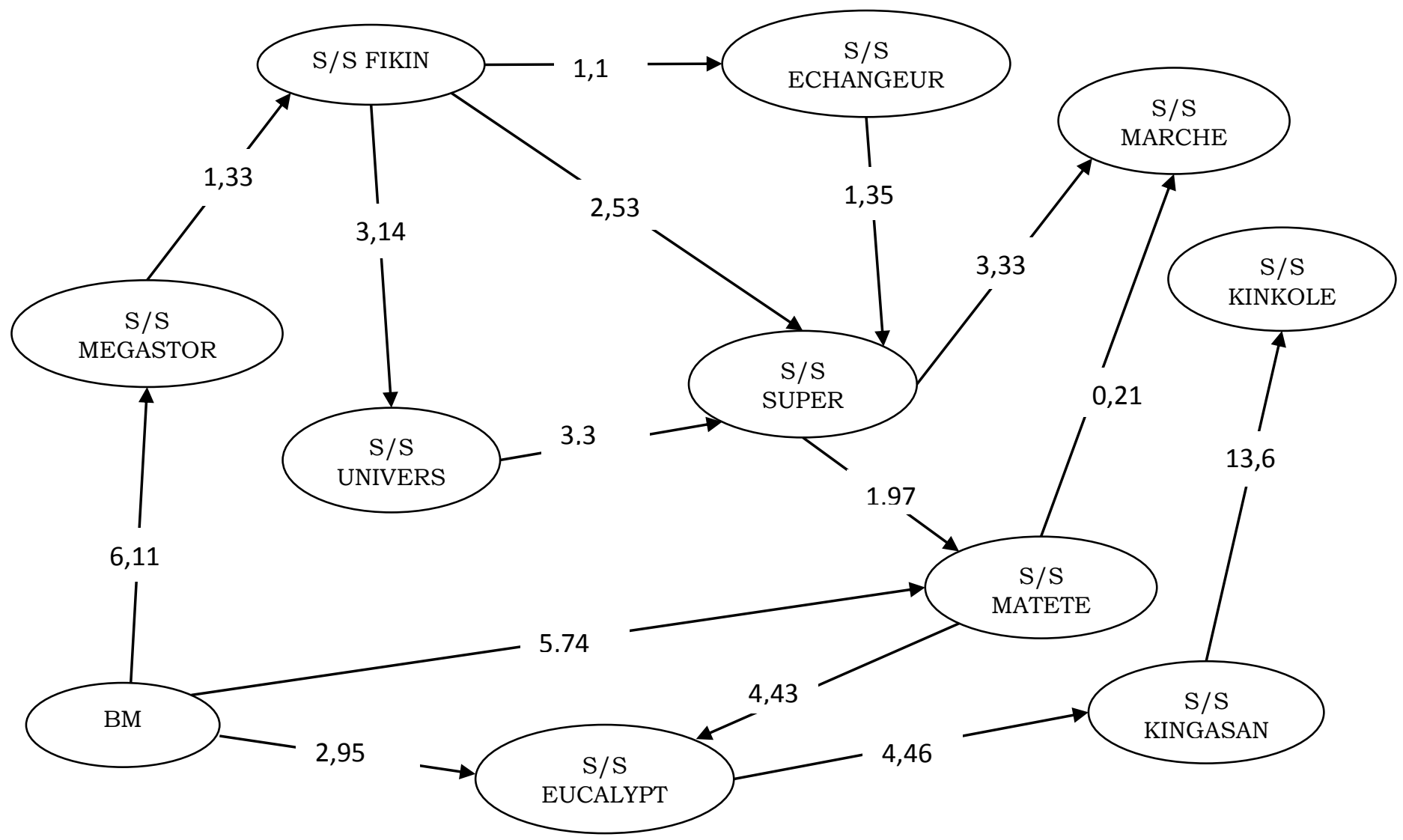

Fig.3 : Total East Network Model with Name of Service Stations 
International Journal of Advances in Scientific Research and Engineering (ijasre), Vol 5 (10), October-2019

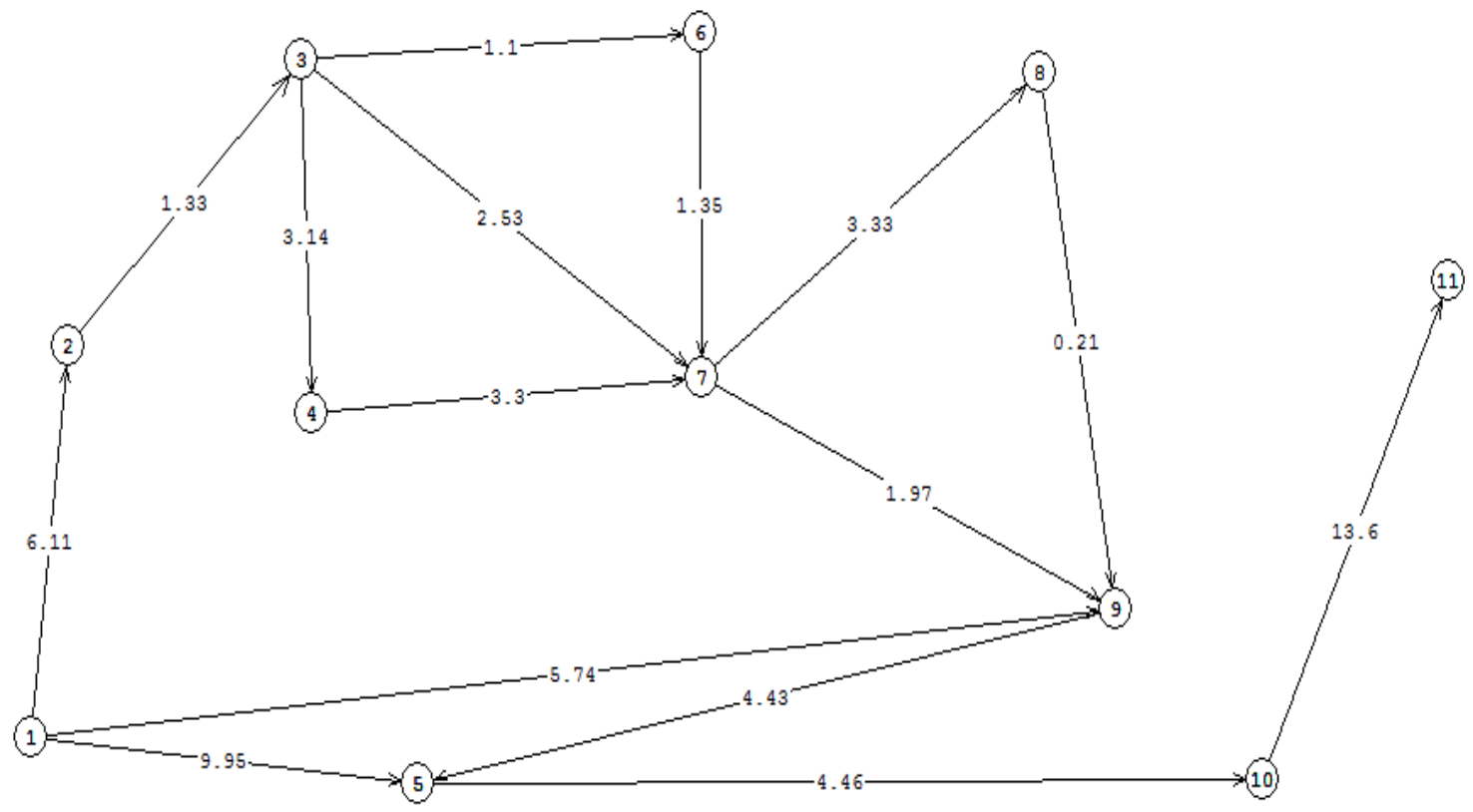

Fig.4 : Total East Network Model without Names of Service Stations

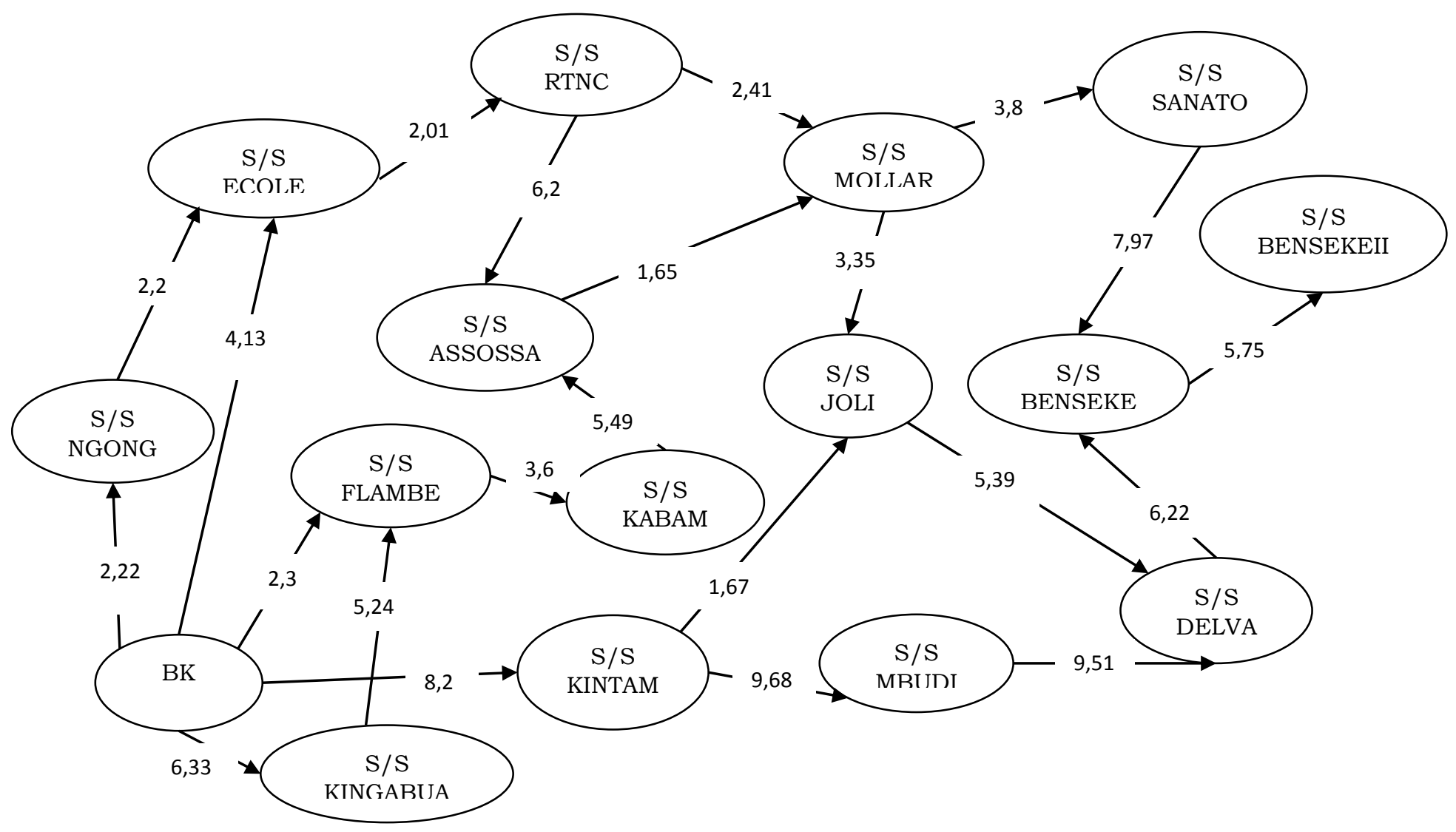

Fig.5 : Total West Network Model with Names of Service Stations 
International Journal of Advances in Scientific Research and Engineering (ijasre), Vol 5 (10), October-2019

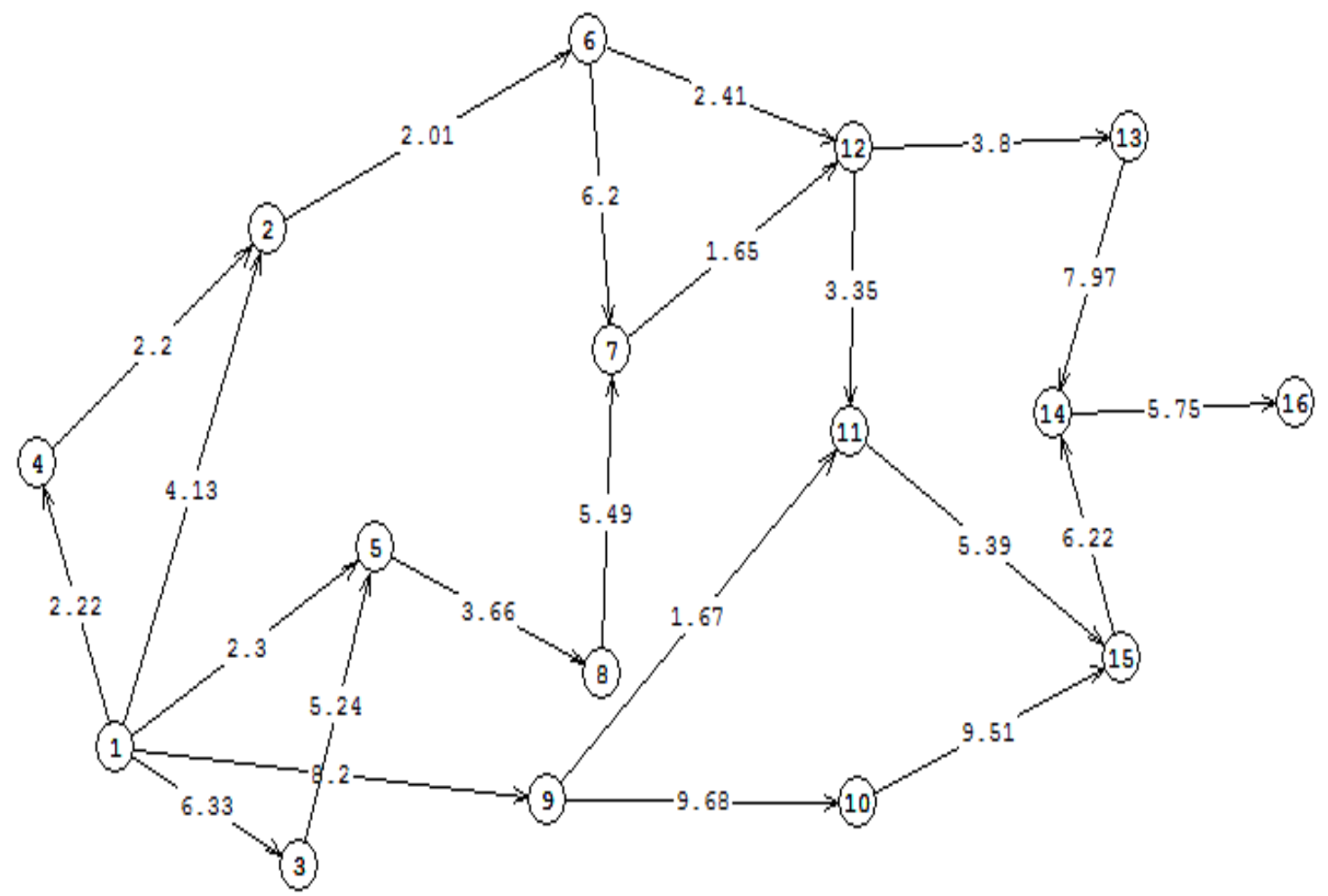

Fig.6 : Total West Network Model without Names of Service Stations 
International Journal of Advances in Scientific Research and Engineering (ijasre), Vol 5 (10), October-2019

\section{RESULTS AND DISCUSSION}

\subsection{Application of the BELLMAN-KALLABA Algorithm}

\subsubsection{Total East Network}

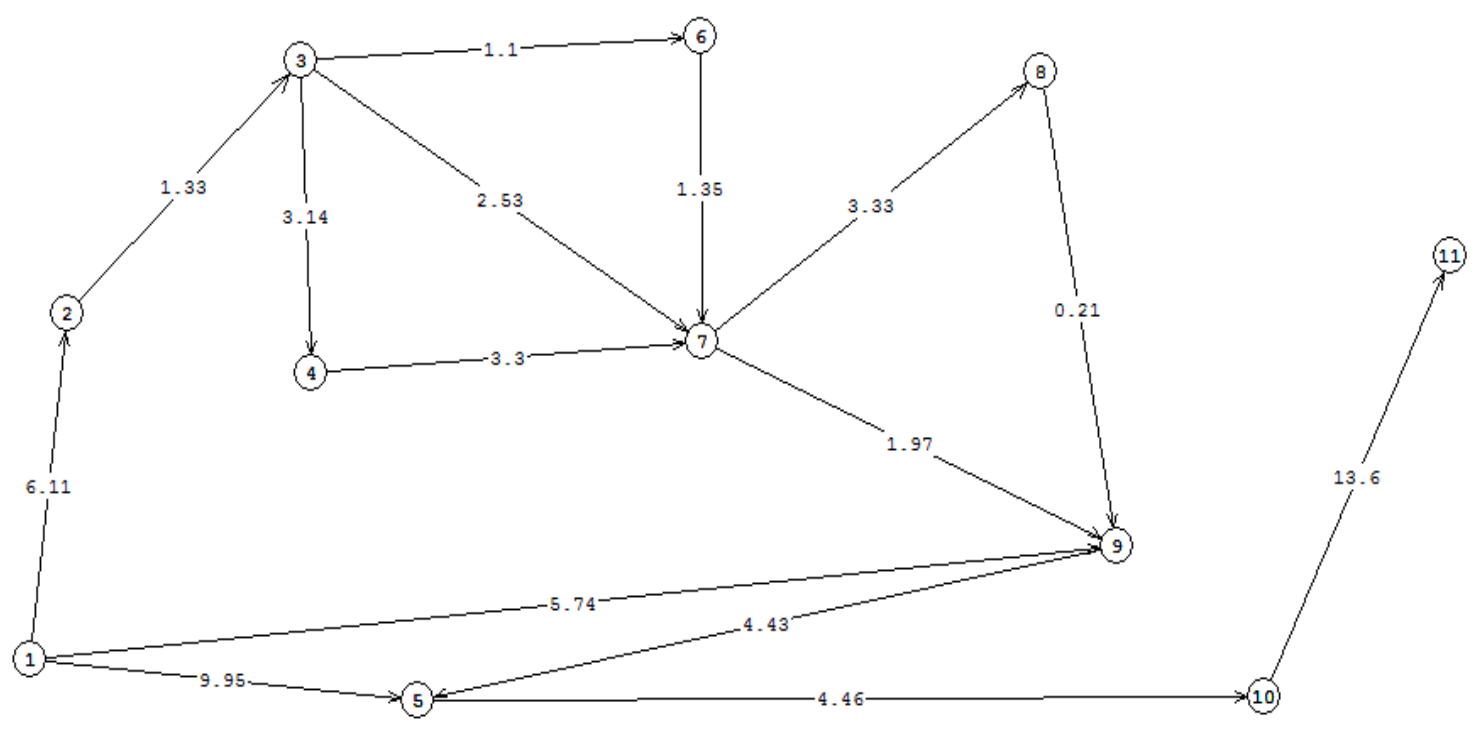

Fig.7 : East Graph

Associated Booléen matrix

Table .2 : Associated Booleen matrix of East Graph

\begin{tabular}{|l|l|l|l|l|l|l|l|l|l|l|l|}
\hline & $\mathrm{X}_{1}$ & $\mathrm{X}_{2}$ & $\mathrm{X}_{3}$ & $\mathrm{X}_{4}$ & $\mathrm{X}_{5}$ & $\mathrm{X}_{6}$ & $\mathrm{X}_{7}$ & $\mathrm{X}_{8}$ & $\mathrm{X}_{9}$ & $\mathrm{X}_{10}$ & $\mathrm{X}_{11}$ \\
\hline $\mathrm{X}_{1}$ & 0 & 1 & 0 & 0 & 1 & 0 & 0 & 0 & 1 & 0 & 0 \\
\hline $\mathrm{X}_{2}$ & 0 & 0 & 1 & 0 & 0 & 0 & 0 & 0 & 0 & 0 & 0 \\
\hline $\mathrm{X}_{3}$ & 0 & 0 & 0 & 1 & 0 & 1 & 1 & 0 & 0 & 0 & 0 \\
\hline $\mathrm{X}_{4}$ & 0 & 0 & 0 & 0 & 0 & 0 & 1 & 0 & 0 & 0 & 0 \\
\hline $\mathrm{X}_{5}$ & 0 & 0 & 0 & 0 & 0 & 0 & 0 & 0 & 0 & 1 & 0 \\
\hline $\mathrm{X}_{6}$ & 0 & 0 & 0 & 0 & 0 & 0 & 1 & 0 & 0 & 0 & 0 \\
\hline $\mathrm{X}_{7}$ & 0 & 0 & 0 & 0 & 0 & 0 & 0 & 1 & 1 & 0 & 0 \\
\hline $\mathrm{X}_{8}$ & 0 & 0 & 0 & 0 & 0 & 0 & 0 & 0 & 1 & 0 & 0 \\
\hline $\mathrm{X}_{9}$ & 0 & 0 & 0 & 0 & 1 & 0 & 0 & 0 & 0 & 0 & 0 \\
\hline $\mathrm{X}_{10}$ & 0 & 0 & 0 & 0 & 0 & 0 & 0 & 0 & 0 & 0 & 1 \\
\hline $\mathrm{X}_{11}$ & 0 & 0 & 0 & 0 & 0 & 0 & 0 & 0 & 0 & 0 & 0 \\
\hline
\end{tabular}


Ordinal function of the graph

$\mathrm{X}_{11} \in \mathrm{R}_{\mathrm{k}}=\mathrm{R}_{9}$

$\mathrm{X}_{10} \in \mathrm{R}_{\mathrm{k}-1}=\mathrm{R}_{8}$

$\mathrm{X}_{5} \in \mathrm{R}_{\mathrm{k}-2}=\mathrm{R}_{7}$

$\mathrm{X}_{9} \in \mathrm{R}_{\mathrm{k}-3}=\mathrm{R}_{6}$

$\mathrm{X}_{8} \in \mathrm{R}_{\mathrm{k}-4}=\mathrm{R}_{5}$

$\mathrm{X}_{7} \in \mathrm{R}_{\mathrm{k}-5}=\mathrm{R}_{4}$

$\mathrm{X}_{4} \in \mathrm{R}_{\mathrm{k}-6}=\mathrm{R}_{3}$

$\mathrm{X}_{3} \in \mathrm{R}_{\mathrm{k}-7}=\mathrm{R}_{2}$

$\mathrm{X}_{2} \in \mathrm{R}_{\mathrm{k}-8}=\mathrm{R}_{1}$

$\mathrm{X}_{0} \in \mathrm{R}_{0}$

\section{Ordering the graph}

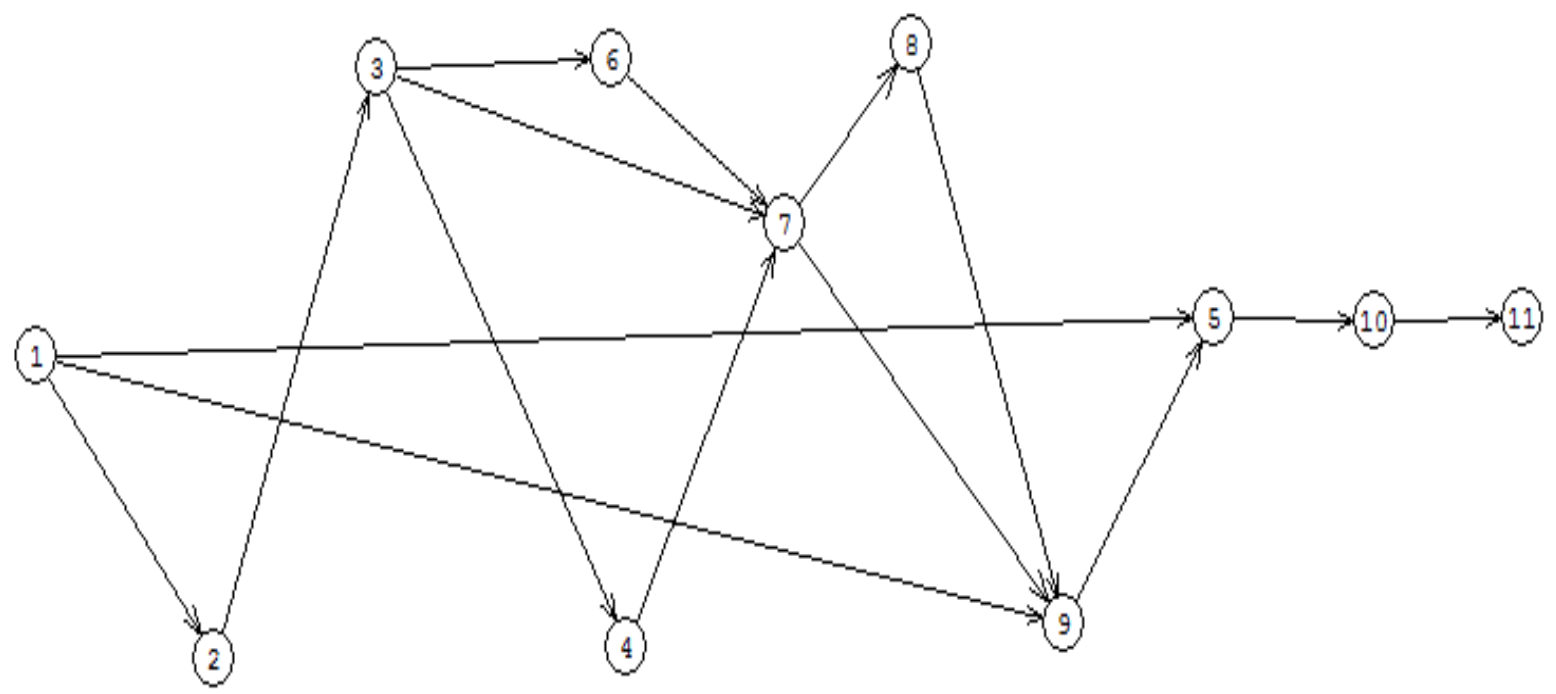

Fig.8 : Total East Network Graph Ordered

\section{Value of paths}

$\mathrm{R}_{0}: \mathrm{f}\left(\mathrm{x}_{1}\right)=0$

$\mathrm{R}_{1}: \mathrm{f}\left(\mathrm{x}_{2}\right)=\mathrm{v}\left(\mathrm{x}_{1}, \mathrm{x} 2\right)=0$

$\mathrm{R}_{2}: \Gamma^{-}\left(\mathrm{x}_{3}\right)=\left\{\mathrm{x}_{2}\right\} \mathrm{f}\left(\mathrm{x}_{3}\right)=\mathrm{f}\left(\mathrm{x}_{2}\right)+\mathrm{v}\left(\mathrm{x}_{2}, \mathrm{x} 3\right)=2,95+1,33=4,28$

$\mathrm{R}_{3}: \mathrm{f}\left(\mathrm{x}_{6}\right)=\mathrm{f}\left(\mathrm{x}_{3}\right)+\mathrm{v}\left(\mathrm{x}_{3}, \mathrm{x} 6\right)=4,28+1,1=5,38$

$-f\left(x_{4}\right)=f\left(x_{3}\right)+v\left(x_{3, x 4}\right)=4,28+3,14=7,42$

$\mathrm{R}_{4}: \Gamma^{-}\left(\mathrm{x}_{7}\right)=\left\{\mathrm{x}_{6}, \mathrm{x} 3, \mathrm{x}_{4}\right\} \mathrm{f}\left(\mathrm{x}_{7}\right)=\operatorname{Min}(5,38+1,35+4,28+2,53 ; 7,42+3,30)$ 
$=\operatorname{Min}(6,78,6,81,10,72)$

$\mathrm{F}\left(\mathrm{x}_{7}\right)=6,78$

$R_{5:} f\left(x_{8}\right)=f\left(x_{7}\right)+v\left(x_{7}, x 8\right)=6,78+3,33 \quad f\left(x_{8}\right)=10,11$

$\mathrm{R}_{2}: \Gamma^{-}\left(\mathrm{x}_{9}\right)=\left\{\mathrm{x}_{8}, \mathrm{x} 7, \mathrm{x} 1\right\} \quad \operatorname{Min} \mathrm{f}(0+2,95,5,74+4,43)=\mathrm{f}\left(\mathrm{x}_{5}\right)$

$\mathrm{F}\left(\mathrm{x}_{5}\right)=2,95$

$R_{8}: f\left(x_{10}\right)=f\left(x_{5}\right)+v\left(x_{5}, x_{10}\right)=2,95+4,46 f\left(x_{10}\right)=7,41$

$\mathrm{R}_{9:} \mathrm{f}\left(\mathrm{x}_{11}\right)=7,41+13,60 \quad \mathrm{f}\left(\mathrm{x}_{11}\right)=21,01$

\section{Optimal paths}

-From the vertex $\mathrm{x}_{11}: \Gamma^{-}\left(\mathrm{x}_{11}\right)=\left\{\mathrm{x}_{10}\right\}: \mathrm{f}\left(\mathrm{x}_{11}\right)-\mathrm{f}\left(\mathrm{x}_{10}\right)=21,01-7,41 \rightarrow \mathrm{f}\left(\mathrm{x}_{11}\right)-\mathrm{f}\left(\mathrm{x}_{10}\right)=\mathrm{v}\left(\mathrm{x}_{10}, \mathrm{x}_{11}\right) ; \rightarrow \mathrm{x}_{10}$

- From the vertex $\mathrm{x}_{10}: \Gamma^{-}\left(\mathrm{x}_{10}\right)=\left\{\mathrm{x}_{5}\right\}: \mathrm{f}\left(\mathrm{x}_{10}\right)-\mathrm{f}\left(\mathrm{x}_{5}\right)=7,41-2,95 \rightarrow \mathrm{f}\left(\mathrm{x}_{10}\right)-\mathrm{f}\left(\mathrm{x}_{5}\right)=4,46=\mathrm{v}\left(\mathrm{x}_{5}, \mathrm{x}_{10}\right) \rightarrow \mathrm{x}_{5}$

- From the vertex $\mathrm{x}_{5:} \Gamma^{-}\left(\mathrm{x}_{5}\right)=\left\{\mathrm{x}_{1}, \mathrm{x} 9\right\}$ :

For $\mathrm{x}_{1}:(2,95-0)=\mathrm{v}\left(\mathrm{x}_{1}, \mathrm{x} 5\right) \rightarrow \mathrm{x}_{1}$

For $\mathrm{x}_{9}:(2,95-5,74) \neq \mathrm{v}\left(\mathrm{x}_{9}, \mathrm{x}_{5}\right)$

- From the vertex x1: $\Gamma^{-}(\mathrm{x} 1)=$ Empty Set

End of the operation

The shortest way will be so: $\mathrm{x}_{1} \rightarrow \mathrm{x}_{5} \rightarrow \mathrm{x}_{10} \rightarrow \mathrm{x}_{11}$

However, the use of the GRIN 4.0 software quickly provides all the most network paths between the depot and each TOTAL East network service station

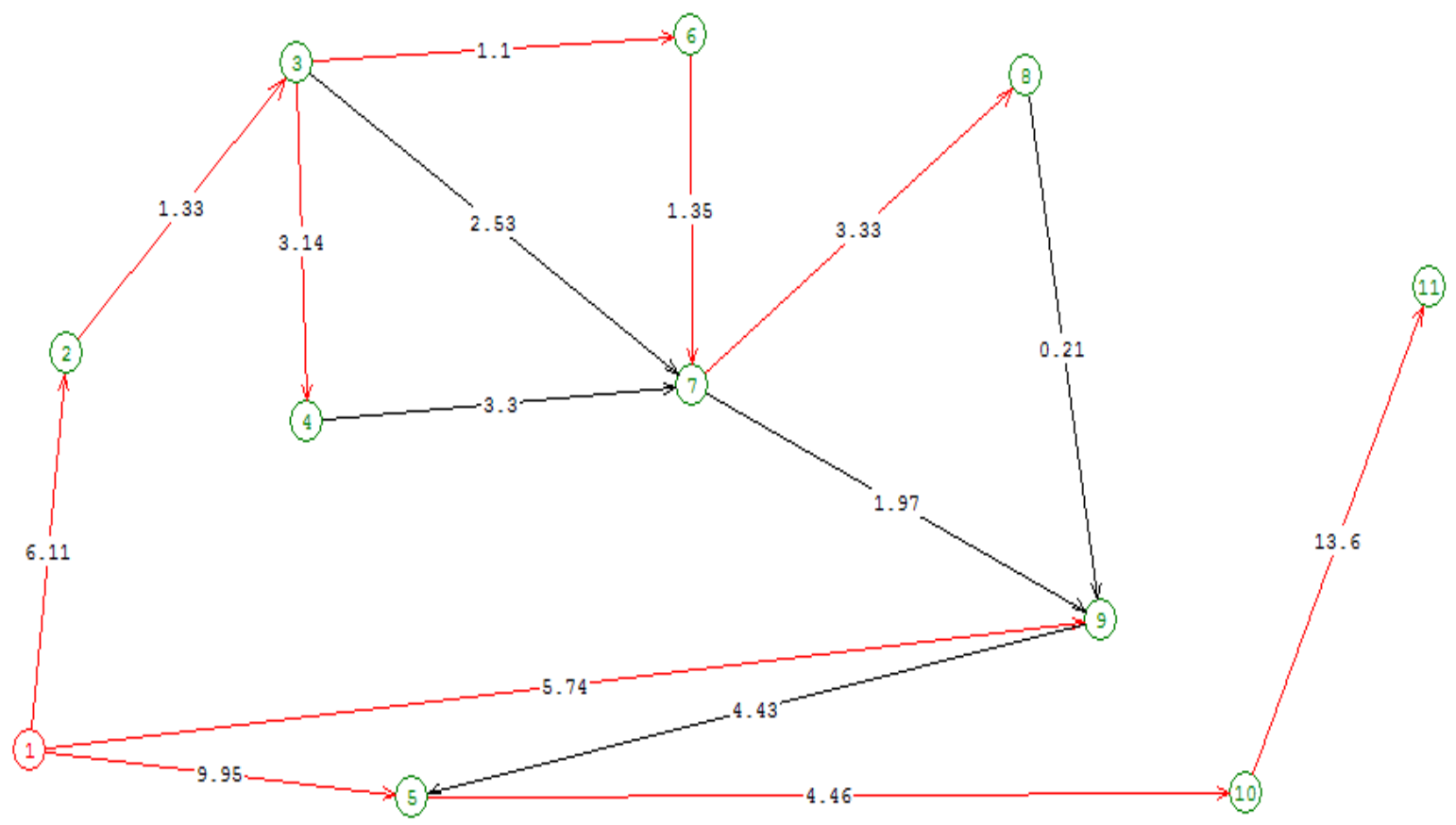

Fig.9 : All Shortest Paths in the Total East Network From the Supply Depot 


\subsubsection{Total West Network}

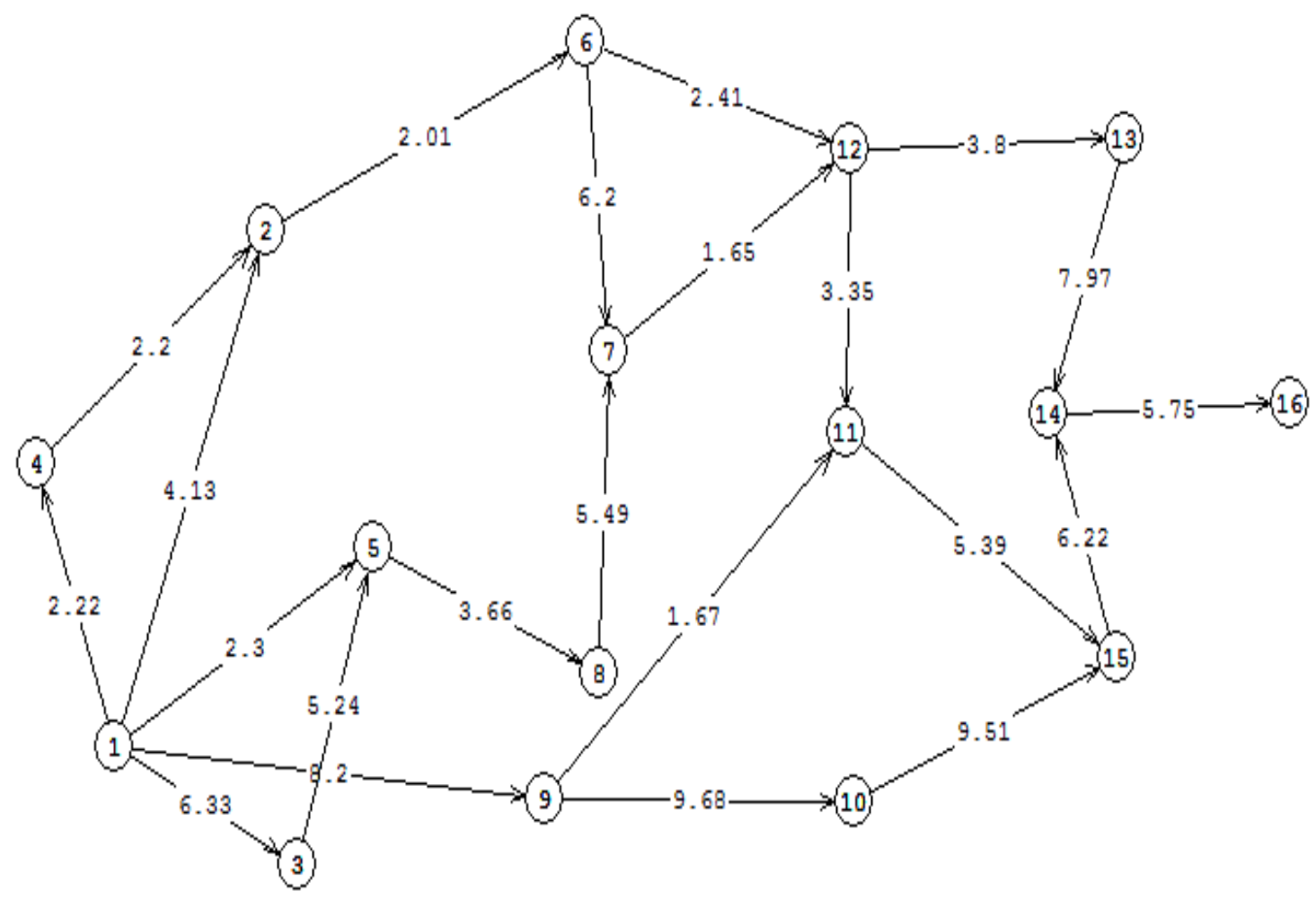

Fig.10 : West Graph

Associated Booléen matrix

Table.3 : Associated matrix of the West graph

\begin{tabular}{|l|l|l|l|l|l|l|l|l|l|l|l|l|l|l|l|l|}
\hline & $\mathrm{X}_{1}$ & $\mathrm{X}_{2}$ & $\mathrm{X}_{3}$ & $\mathrm{X}_{4}$ & $\mathrm{X}_{5}$ & $\mathrm{X}_{6}$ & $\mathrm{X}_{7}$ & $\mathrm{X}_{8}$ & $\mathrm{X}_{9}$ & $\mathrm{X}_{10}$ & $\mathrm{X}_{11}$ & $\mathrm{X}_{12}$ & $\mathrm{X}_{13}$ & $\mathrm{X}_{14}$ & $\mathrm{X}_{15}$ & $\mathrm{X}_{16}$ \\
\hline $\mathrm{X}_{1}$ & 0 & 1 & 1 & 1 & 1 & 0 & 0 & 0 & 1 & 0 & 0 & 0 & 0 & 0 & 0 & 0 \\
\hline $\mathrm{X}_{2}$ & 0 & 0 & 0 & 0 & 0 & 1 & 0 & 0 & 0 & 0 & 0 & 0 & 0 & 0 & 0 & 0 \\
\hline $\mathrm{X}_{3}$ & 0 & 0 & 0 & 0 & 1 & 0 & 0 & 0 & 0 & 0 & 0 & 0 & 0 & 0 & 0 & 0 \\
\hline $\mathrm{X}_{4}$ & 0 & 1 & 0 & 0 & 0 & 0 & 0 & 0 & 0 & 0 & 0 & 0 & 0 & 0 & 0 & 0 \\
\hline $\mathrm{X}_{5}$ & 0 & 0 & 0 & 0 & 0 & 0 & 0 & 1 & 0 & 0 & 0 & 0 & 0 & 0 & 0 & 0 \\
\hline $\mathrm{X}_{6}$ & 0 & 0 & 0 & 0 & 0 & 0 & 1 & 0 & 0 & 0 & 0 & 1 & 0 & 0 & 0 & 0 \\
\hline $\mathrm{X}_{7}$ & 0 & 0 & 0 & 0 & 0 & 0 & 0 & 0 & 0 & 0 & 0 & 1 & 0 & 0 & 0 & 0 \\
\hline $\mathrm{X}_{8}$ & 0 & 0 & 0 & 0 & 0 & 0 & 1 & 0 & 0 & 0 & 0 & 0 & 0 & 0 & 0 & 0 \\
\hline $\mathrm{X}_{9}$ & 0 & 0 & 0 & 0 & 0 & 0 & 0 & 0 & 0 & 1 & 1 & 0 & 0 & 0 & 0 & 0 \\
\hline $\mathrm{X}_{10}$ & 0 & 0 & 0 & 0 & 0 & 0 & 0 & 0 & 0 & 0 & 0 & 0 & 0 & 0 & 1 & 0 \\
\hline $\mathrm{X}_{11}$ & 0 & 0 & 0 & 0 & 0 & 0 & 0 & 0 & 0 & 0 & 0 & 0 & 0 & 0 & 1 & 0 \\
\hline $\mathrm{X}_{12}$ & 0 & 0 & 0 & 0 & 0 & 0 & 0 & 0 & 0 & 1 & 0 & 0 & 1 & 0 & 0 & 0 \\
\hline $\mathrm{X}_{13}$ & 0 & 0 & 0 & 0 & 0 & 0 & 0 & 0 & 0 & 0 & 0 & 0 & 0 & 1 & 0 & 0 \\
\hline $\mathrm{X}_{14}$ & 0 & 0 & 0 & 0 & 0 & 0 & 0 & 0 & 0 & 0 & 0 & 0 & 0 & 0 & 0 & 1 \\
\hline $\mathrm{X}_{15}$ & 0 & 0 & 0 & 0 & 0 & 0 & 0 & 0 & 0 & 0 & 0 & 0 & 0 & 1 & 0 & 0 \\
\hline $\mathrm{X}_{16}$ & 0 & 0 & 0 & 0 & 0 & 0 & 0 & 0 & 0 & 0 & 0 & 0 & 0 & 0 & 0 & 0 \\
\hline
\end{tabular}


International Journal of Advances in Scientific Research and Engineering (ijasre), Vol 5 (10), October-2019

Ordinal function of the graph

$\mathrm{x}_{16} \in \mathrm{R}_{\mathrm{k}}: \mathrm{R}_{9}$

$\mathrm{x}_{14} \in \mathrm{R}_{\mathrm{k}-1:} \mathrm{R}_{8}$

$\mathrm{x}_{13}, \mathrm{X}_{15} \in \mathrm{R}_{\mathrm{k}-2}: \mathrm{R}_{7}$

$\mathrm{x}_{11}, \mathrm{x}_{10} \in \mathrm{R}_{\mathrm{k}-3}: \mathrm{R}_{6}$

$\mathrm{X}_{9,} \mathrm{X}_{12} \in \mathrm{R}_{\mathrm{k}-4}: \mathrm{R}_{5}$

$\mathrm{X}_{7} \in \mathrm{R}_{\mathrm{k}-5}: \mathrm{R}_{4}$

$\mathrm{X}_{8}, \mathrm{X}_{6} \in \mathrm{R}_{\mathrm{K}-6}: \mathrm{R}_{3}$

$\mathrm{x}_{5}, \mathrm{x}_{2} \in \mathrm{R}_{\mathrm{k}-7}: \mathrm{R}_{2}$

$\mathrm{X}_{4}, \mathrm{X}_{3} \in \mathrm{R}_{\mathrm{k}-8}: \mathrm{R}_{1}$

$\mathrm{x}_{1} \in \mathrm{R}_{0}$

Ordering the graph

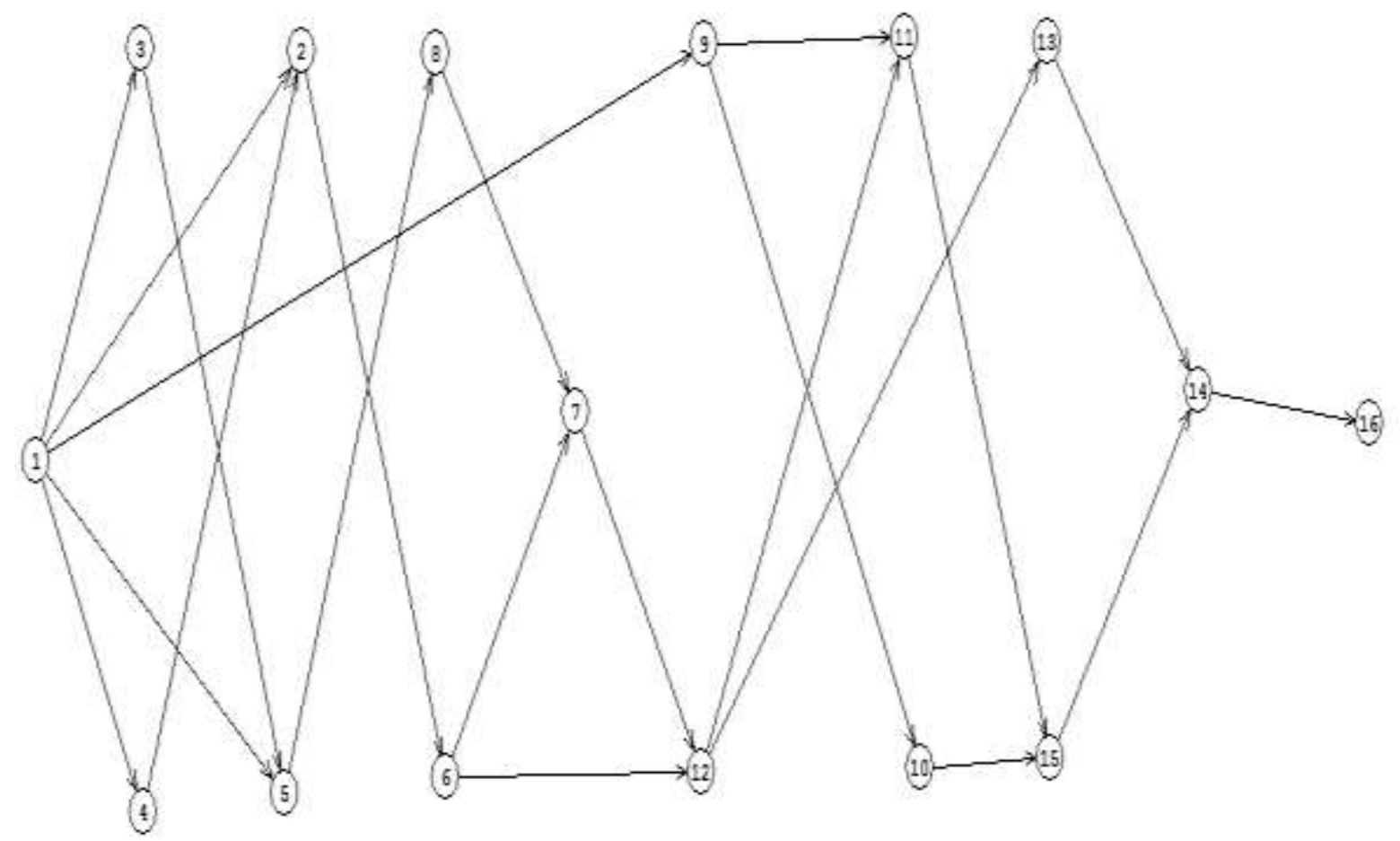

Fig.11 : Total West Network Graph Ordered 
International Journal of Advances in Scientific Research and Engineering (ijasre), Vol 5 (10), October-2019

Value of paths

$\mathrm{R}_{0:} \mathrm{f}\left(\mathrm{x}_{1}\right)=0$

$\mathrm{R}_{1}:-\mathrm{f}\left(\mathrm{x}_{3}\right)=6,33$

$-\mathrm{f}\left(\mathrm{x}_{4}\right)=2,22$

$\mathrm{R}_{2}:-\Gamma^{-}\left(\mathrm{x}_{2}\right)=\left\{\mathrm{x}_{1}, \mathrm{x}_{4}\right\} \rightarrow-\mathrm{f}\left(\mathrm{x}_{2}\right)=\operatorname{Min}\left\{\mathrm{f}\left(\mathrm{x}_{1}\right)+\mathrm{v}\left(\mathrm{x}_{1}, \mathrm{x}_{2}\right) ; \mathrm{f}\left(\mathrm{x}_{4}\right)+\mathrm{v}\left(\mathrm{x}_{4}, \mathrm{x}_{2}\right)\right\}$

$\mathrm{f}\left(\mathrm{x}_{2}\right)=(4,13 ; 2,22+2,20)$

$\mathrm{f}\left(\mathrm{x}_{2}\right)=4,13$

$\Gamma^{-}(\mathrm{x} 5)=\left\{\mathrm{x}_{1}, \mathrm{x} 3\right\} \rightarrow \mathrm{f}(\mathrm{x} 5)=\operatorname{Min}(2,3 ; 6,33+5,24)$

$-f(x 5)=2,30$

$\mathrm{R}_{3}:-\mathrm{f}\left(\mathrm{x}_{8}\right)=2,30+3,66$

$\mathrm{f}\left(\mathrm{x}_{8}\right)=5,96$

$-\mathrm{f}\left(\mathrm{x}_{6}\right)=4,13+2,01$

$\mathrm{f}\left(\mathrm{x}_{6}\right)=6,14$

$\mathrm{R}_{4}: \Gamma^{-}\left(\mathrm{x}_{7}\right)=\left\{\mathrm{x}_{8}, \mathrm{x} 6\right\} \rightarrow-\mathrm{f}\left(\mathrm{x}_{7}\right)=\operatorname{Min}(5,96+5,49 ; 6,14+6,20)$

$\mathrm{f}\left(\mathrm{x}_{7}\right)=11,45$

$R_{5}:-f\left(x_{9}\right)=8,20$

$\Gamma^{-}\left(\mathrm{x}_{12}\right)=\left\{\mathrm{x}_{7}, \mathrm{x} 6\right\}$

$-\mathrm{f}\left(\mathrm{x}_{12}\right)=\operatorname{Min}(11,45+1,65 ; 6,14+2,41)$

$\mathrm{f}\left(\mathrm{x}_{12}\right)=8,55$

$\mathrm{R}_{6}: \Gamma^{-}\left(\mathrm{x}_{11}\right)=\left\{\mathrm{x}_{9}, \mathrm{x} 12\right\}$

$-\mathrm{f}\left(\mathrm{x}_{11}\right)=\operatorname{Min}(8,20+1,67 ; 8,55+3,35)$

$f\left(x_{11}\right)=9,87$

$-\mathrm{f}\left(\mathrm{x}_{10}\right)=8,20+9,68$

$\mathrm{f}\left(\mathrm{x}_{10}\right)=17,88$

$\mathrm{R}_{7}:-\mathrm{f}\left(\mathrm{x}_{13}\right)=8,55+3,8$

$\mathrm{f}\left(\mathrm{x}_{13}\right)=12,35$

$\Gamma^{-}\left(\mathrm{x}_{15}\right)=\left\{\mathrm{x}_{11}, \mathrm{x} 10\right\}$

$-\mathrm{f}\left(\mathrm{x}_{15}\right)=\operatorname{Min}(9,87+5,39 ; 17,88+9,51)$

$\mathrm{f}\left(\mathrm{x}_{15}\right)=15,26$

$\mathrm{R}_{8}: \Gamma^{-}\left(\mathrm{x}_{14}\right)=\left\{\mathrm{x}_{13}, \mathrm{x}_{15}\right\}$

$-\mathrm{f}\left(\mathrm{x}_{14}\right)=\operatorname{Min}(12,35+7,97 ; 15,26+6,22)$

$f\left(x_{14}\right)=20,32$

$R_{9}:-f\left(x_{16}\right)=20,32+5,75$

$f\left(x_{16}\right)=26,07$ 


\section{Optimal paths}

From the vertex $\mathrm{x}_{16}: \Gamma^{-}(\mathrm{x} 16)=\left\{\mathrm{x}_{14}\right\}$

$$
\begin{aligned}
& \mathrm{f}\left(\mathrm{x}_{16}\right)-\mathrm{f}\left(\mathrm{x}_{14}\right)=5,75=\mathrm{v}\left(\mathrm{x}_{14}, \mathrm{x} 16\right) \\
& \quad \rightarrow \mathrm{x}_{14}
\end{aligned}
$$

From the vertex $\mathrm{x}_{14:} \Gamma^{-}\left(\mathrm{x}_{14}\right)=\left\{\mathrm{x}_{13}, \mathrm{x} 15\right\}$

$$
\begin{aligned}
\mathrm{x}_{13} & \rightarrow 20,32-12,35=\mathrm{v}\left(\mathrm{x}_{13}, \mathrm{x} 14\right) \\
& \rightarrow \mathrm{x}_{13} \\
\mathrm{x}_{15} & \rightarrow 20,32-15,26 \neq \mathrm{v}\left(\mathrm{x}_{15}, \mathrm{x} 14\right)
\end{aligned}
$$

From the vertex $\mathrm{x}_{13:} \Gamma^{-}\left(\mathrm{x}_{13}\right)=\left\{\mathrm{x}_{12}\right\}$

$$
\begin{aligned}
\mathrm{X}_{12} & \rightarrow 12,35-8,55=\mathrm{v}\left(\mathrm{x}_{12}, \mathrm{x} 13\right) \\
& \rightarrow \mathrm{x}_{12}
\end{aligned}
$$

From the vertex $\mathrm{x}_{12:} \Gamma^{-}\left(\mathrm{x}_{12}\right)=\left\{\mathrm{x}_{7}, \mathrm{x} 6\right\}$

$$
\begin{aligned}
& \mathrm{x}_{7} \rightarrow 8,55-11,45 \neq \mathrm{v}\left(\mathrm{x}_{6}, \mathrm{x} 12\right) \\
& \mathrm{x}_{6} \rightarrow 8,55-6,14=\mathrm{v}\left(\mathrm{x}_{6}, \mathrm{x} 12\right) \\
& \rightarrow \mathrm{x}_{6}
\end{aligned}
$$

From the vertex $\mathrm{x}_{6:} \Gamma^{-}\left(\mathrm{x}_{6}\right)=\left\{\mathrm{x}_{2}\right\}$

$$
\begin{aligned}
\mathrm{x}_{2} & \rightarrow 6,14-4,13=\mathrm{v}\left(\mathrm{x}_{2}, \mathrm{x} 6\right) \\
& \rightarrow \mathrm{x}_{2}
\end{aligned}
$$

From the vertex $\mathrm{x}_{2:} \Gamma^{-}(\mathrm{x} 2)=\left\{\mathrm{x}_{1}, \mathrm{x}_{4}\right\}$

$$
\begin{aligned}
& \mathrm{x}_{4} \rightarrow 4,13-2,22 \neq \mathrm{v}\left(\mathrm{x}_{4}, \mathrm{x} 2\right) \\
& \mathrm{x}_{1} \rightarrow 4,13-0=\mathrm{v}\left(\mathrm{x}_{2}, \mathrm{x} 1\right) \\
& \rightarrow \mathrm{x}_{1}
\end{aligned}
$$

From the vertex $\mathrm{x}_{1:} \Gamma^{-}\left(\mathrm{x}_{1}\right)=$ Empty Set

End of the operation

The shortest path is $\left(\mathrm{x}_{1}, \mathrm{x}_{2}, \mathrm{x}_{6}, \mathrm{x}_{12}, \mathrm{x}_{13}, \mathrm{x}_{14}, \mathrm{x}_{16}\right)$ 
However, the use of the GRIN 4.0 software quickly provides all the most network paths between the depot and each TOTAL West network service station

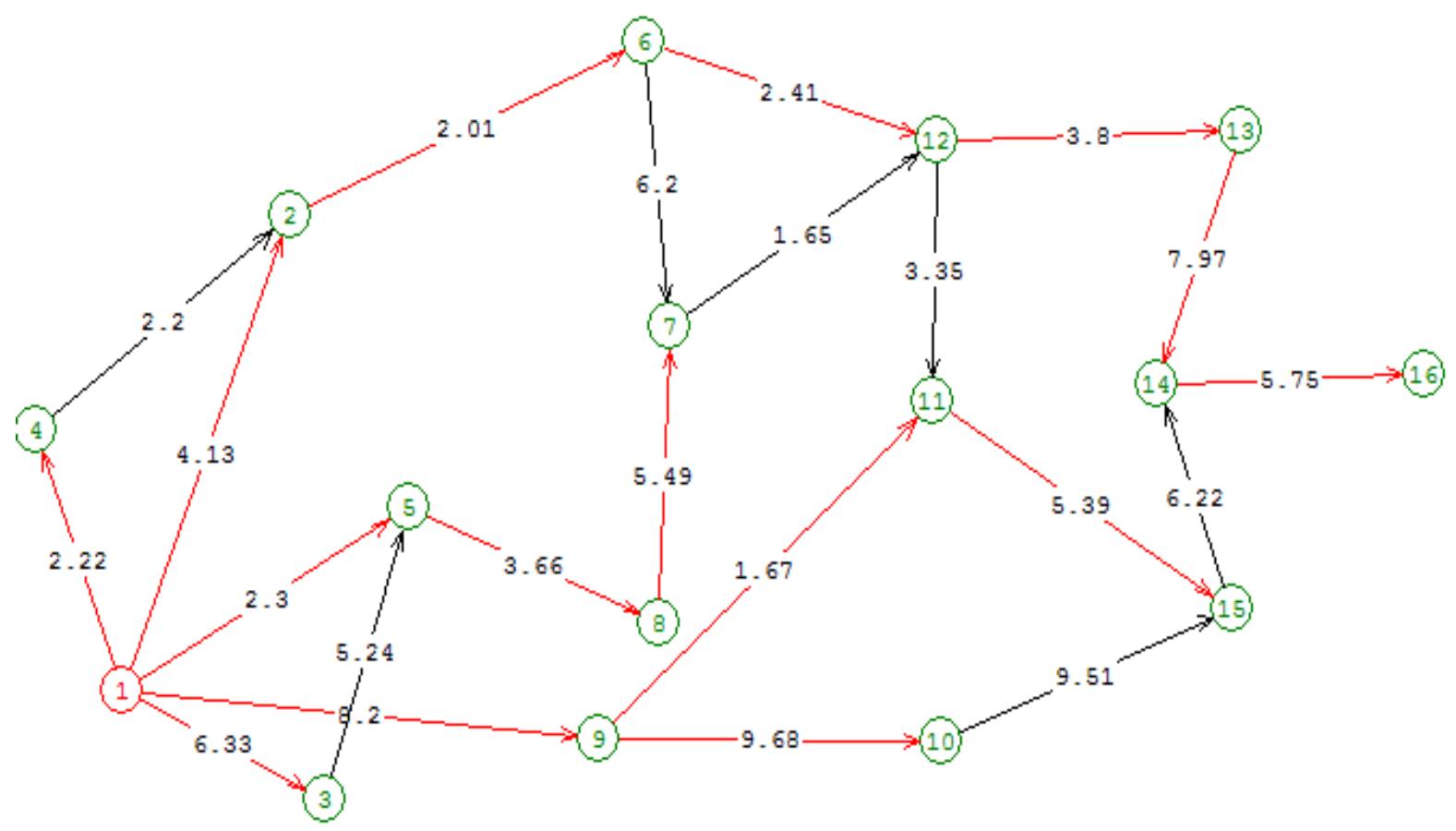

Fig.12 : All shortest paths in the TOTAL WEST network from the supply depot

These routes are the best way to navigate both networks from the depots to the last gas station. However, there are several possibilities for reaching the last station of the network from the depot whose distance is in all cases greater than that of the shortest path; this is a waste of time, resources, manpower and exposure extended to the risks. Stations which do not form paths of length less than or equal to 3 are supplied by following the shortest path from the root which is the base SEP to the receiving service station. Since not all 2 networks are strongly connected, there is no way to visit all service stations in the network on a single route because there are no Hamiltonian paths. Some stations of the network are provided with tanks of all 3 products sold in the network that is to say station with tanks for three different products. For such stations, each race will be carried out by two tank trucks which are respectively mono and bi-compartmented or by a single tri-compartmented truck in order to distribute throughout the network the three different products in a single race.

However, the results obtained previously allow, not only the optimal management of the tours, but also the optimization of the performance criteria. In some cases, it happens to supply a service station $\mathrm{i}$, without visiting Ei, that is to say, without visiting all the service stations said on the way to station $i$. This particular case will therefore be solved using the paths of the figures above

Thus, it is clear that there is a methodological tool for optimal race management based on the mathematical modeling of the network. 


\section{GENERAL CONCLUSION}

Optimizing the supply of fuels from a distribution network (service stations) consists in determining how to best distribute several fuels (mainly gasoline, kerosene and diesel fuel) to service stations from one or more deposits according to a chosen planning horizon and according to optimal routes.in other words, how to enumerate, without repetition and redundancy, all the optimal elemental paths of the fuel distribution network from an established model. Therefore, from the fuel distribution network modeling, for each path, the optimal routes, the stations to be visited, the routes to be made, the trucks to be used, the quantities to be delivered for each product and their assignment must be determined. Trucks taking account for quality and safety requirements by ensuring that no customer stations are out of stock.

The results obtained in this study show that the use of optimal routes during tanker truck tours helps to improve safety management and reduce operating costs.

Otherwise, the use of non-optimal routes during tanker truck tours exposes the various forms of risk that can cause material and human damage.

\section{REFERENCE}

1. Federgruen, A. and Zipkin, P. (1984) A combined vehicle routing and inventory allocation problem, Operations Research, Vol. 32, 1019-1037.

2. Camille Lemesre, Gestion des interdépendances reliées à l'utilisation des produits pétroliers, Ecole polytechnique de Montréal, 2013.

3. Golden, B., Assad, A. and Dahl, R. (1984) Analysis of a large scale vehicle routing problem with an inventory component. Large Scale Systems, Vol. 7, 181-190

4. Chien, T., Balakrishnan, A. and Wong, R.T. (1989) An integrated inventory allocation and vehicle routing problem, Transportation Science, Vol. 23, 67-7.

5. M. Dror et al, A computational comparison of the inventorying routing problem, annals of Operations research, p 3-23, 1985

6. Anily, S and Federgruen, A. (1990) One warehouse multiple retailer system with vehicle routing costs, Management Science, Vol. 36, No. 1, 92-114.

7. Assad, A., B. Golden, R. Dahl and M. Dror. 1982. Design of an Inventory- Routing System for a Large PropaneDistribution Firm. Working Paper, Uni- versity of Maryland.

8. Brodheim, E., and G. Prastacos. 1979. The Long Island Blood Distribution System as a Prototype for Regional BloodManagement. Interfaces 9, 3-35.

9. Fisher, M., and R. Jaikumar. 1978. A Decomposition Algorithm for Large- Scale Vehicle Routing, Working Paper. Dept. of Decision Sciences, University of Pennsylvania, Philadelphia.

10. Gillett, B., and J. Johnson. 1976. Multi-Terminal Vehicle-Dispatch Algo- rithm. Omega 4, 711-718.

11. Geoffrion, A. 1972. Generalized Benders' Decomposition. J. Optim. Theor. Apple. 10, 237-260.

12. Geoffrion, A., and G. Graves. 1974. Multicommodity Distribution System Design by Benders' Decomposition. Mgmt. Sci. 20, 822-844.

13. nstitut Canadiènne des Produits Pétroliers, Manuel du Chauffeur de véhicules de Produits Pétroliers Professionnel, 2009.

14. M Dror et al, A computational comparison of the inventorying routing problem, annals of Operations research, $\mathrm{p}$ 3-23, 1985 